\title{
Saving and management of income as part of financial literacy in today's globalized world
}

\author{
Markéta Beranová ${ }^{1, *}$, and Miroslava Navrátilová ${ }^{1}$ \\ ${ }^{1}$ Czech University of Life Sciences in Prague, Faculty of Economics and Management, Department \\ of Economics, Kamýcká 129, Prague, 165 21, Czech Republic
}

\begin{abstract}
Research background: The role of knowledge and information in today's globalized world is growing. In today's globalized world, moreover, under the influence of the COVID-19 pandemic, financial management is crucial. Purpose of the article: The aim of the presented article is to evaluate financial literacy with a focus on saving part of income as a reserve amongst the young university students.

Methods: Primary data were obtained by a quantitative research using a questionnaire survey $(n=1437)$ in 2018 amongst full time bachelor and master degree students at three selected universities. Selected universities are focus on economy and agriculture and each of them is from another region of the Czech Republic. In the analytical part of article was used testing of statistical hypotheses.

Findings \& Value added: The attitude of the respondents was examined by asking whether they store a part of their income as a reserve in case of an unforeseen situation, i.e., whether they form a kind of financial reserve. Of the total number of respondents, $76.83 \%(1,104)$ declared that they saved part of their income for unforeseen situations or for other needs. Other respondents, $23.17 \%$ (333), stated that they do not create such a reserve. Statistical evaluation proved a dependence between the sex of respondents and the responses mentioned above (the structure of the responses in relation to the gender of the respondents shows that more than half of those who answered that they save part of their income as a reserve are women).
\end{abstract}

Keywords: globalized world; income; saving; student; university

JEL Classification: E22; F65; G1

\section{Introduction}

In today's globalized world, the digitalisation of the financial market and access to credit are growing. Global trends - transition in the superannuation landscape, rise in longevity, longlasting footprints of financial and health crises - need for financial literacy of youth as a best practice for consumer and whole society (Goyal and Kumar, 2020).

\footnotetext{
* Corresponding author: mberanova@pef.czu.cz
} 
Organization for Economic Co-operation and Development (OECD) (2018) defines financial literacy as "The combination of awareness, knowledge, skills, attitude and behaviour necessary to make sound financial decisions and ultimately achieve individual financial well-being". Individual authors interpret the concept of financial literacy in different ways. For example: Financial literacy includes an understanding of basic financial concepts and the ability to work with numbers in a financial context. The ultimate goal is to ensure that consumers can address their financial issues exclusively and respond properly to news and events that may affect their financial well-being (Morgan and Trinh, 2017).

The management of funds is crucial for each individual and for society as a whole. The factors influencing people's saving behaviour is important to ensure the financial stability of both person, individually, and country, at large (Gilenko and Chernova, 2021). Everyone who want to prosper in their finances must not only have high financial literacy, but also good financial management skills. Good financial management of finances is the main key to achieving a sound financial situation (Yuesti et al., 2020; Goyal and Kumar, 2021).

As Kurowski (2021) says "The health crisis has highlighted the need for effective household budget management.bThe cessation of operations by numerous companies and the temporary loss of income by many individuals during the coronavirus pandemic have shown how important it is to properly manage personal finances. In this respect, the financial education of a society plays an invaluable role”.

The aim of this paper is based on primary research conducted at selected universities in the Czech Republic to assess the level of financial literacy of full-time bachelor's and master's degree students focuses on saving and management of income.

The theoretical framework is presented in the Introduction. The Methods chapter deals with the method of performing the primary research and the description of the surveyed sample of respondents in terms of basic sociodemographic characteristics. The Results and Discussion chapter presents the results of the survey and includes a discussion and a comparison of the outcomes of our research with similar surveys in terms of the investigated issues. The most important findings are shown in the Conclusion chapter.

\section{Methods}

The theoretical framework of this article has been elaborated through the method of document research using scientific articles. Primary data were collected using a questionnaire survey. The respondents were full-time students at three selected universities in the Czech Republic focused, among other things, on agriculture, forestry, and veterinary science. These were the University of South Bohemia in České Budějovice (hereinafter referred to as USB), the Mendel University in Brno (hereinafter referred to as MEU), and the Czech University of Life Sciences in Prague (hereinafter referred to as CZU). At each university, the researchers approached both respondents studying at the faculties focused on economics (at USB this was the Faculty of Economics, at MEU it was the Faculty of Business and Economics, and at CZU it was the Faculty of Economics and Management) and respondents studying at faculties not specializing in economics (at USB this was the Faculty of Agriculture, at MEU it was the Faculty of Agri Sciences, and at CZU it was the Faculty of Environmental Sciences). In total, $1,437(\mathrm{n}=1,437)$ respondents took part in the primary research. The sample was determined based on quota sampling and represented $14 \%$ of the total number of students at the selected faculties.

Basic sociodemographic factors of the reference group of respondents were as follows (at the same time, each of these characteristics stands for one investigated variable):

Table 1. Sociodemographic factors of respondents in $\%$. 


\begin{tabular}{|c|c|c|}
\hline \multirow{2}{*}{ Level of study } & Male & 42.52 \\
\cline { 2 - 3 } & Bachelor's degree (BD) & 66.32 \\
\hline \multirow{2}{*}{ Field of Study } & Master's degree (MD) & 33.68 \\
\cline { 2 - 3 } & Economic studies (ECO) & 63.40 \\
\hline \multirow{3}{*}{ University } & Non-economic studies (NON-ECO) & 33.60 \\
\cline { 2 - 3 } & CZU & 59.29 \\
\cline { 2 - 3 } & USB & 18.02 \\
\hline \multicolumn{2}{|c|}{ MEU } & 22.69 \\
\hline
\end{tabular}

Source: own research (2018)

\section{Statistical Tools for Analysis}

The contingency table is usedit for transparent visualization of mutual relations of two statistical variables. The type of the contingency table is given by the number of rows $r$ and the number of columns s, it means $r \times s$ (Hendl, 2009). Obviously, $\chi^{2}$ is a measure of the overall dissimilarity of $n_{i j}$ and $m_{i j}$. The greater the difference between the observed and the expected values, the higher the test statistic $\chi^{2}$.

$$
\begin{gathered}
m_{i j}=\frac{n_{i} \cdot n_{j}}{n} \\
\chi^{2}=\sum_{i=1}^{r} \sum_{j=1}^{s}\left(n_{i j}-m_{i j}\right)^{2} / m_{i j}
\end{gathered}
$$

$i$ and $j$ are indices of rows and columns, nij are observed frequencies, ni and nj are marginal totals, $\mathrm{n}$ is grand total of observations, mij are expected frequencies. We compare $\chi^{2}$ to the critical value $\chi^{2}$ with a chi-square distribution of (r-1) (s-1) degrees of freedom at the chosen level of significance $(\alpha=5 \%)$. We reject the hypothesis if $\chi^{2}$ is larger than the table value. This test is valid asymptotically and, thus, can only be applied if there are enough observations. All expected values ought to be higher than one [9]; at the same time, the table should not contain more than $20 \%$ of theoretical incidence rates (frequencies) of less than 5 . Where zero values occur in any of the fields, we proceed to analyse a derived table, created by merging a small number of categories (Hindls, 2007). Cramer's V was used to determine the degree of association between the variables. Additionally, the method of adjusted residuals was applied. The calculation of adjusted residuals indicated precisely the location of the dependency. The results of adjusted residuals are included in the tables for zero hypotheses. The principle of adjusted residuals is based on comparing the values in the cells of the contingency table with the critical value of 2 (or 1.96). The comparison was performed and, considering that wherever the value in a cell equals or exceeds $2(-2)$ a statistically significant difference exists, the dependency was confirmed. This method was enhanced by the sign scheme. Information on where the assumption of independence of both the compared characteristics was violated could be obtained through this method.

The data analysis was focused on the following tested hypotheses.

- H01: Whether a respondent saves part of his income as a reserve does not depend on gender.

- H02: Whether a respondent saves part of his income as a reserve does not depend on the university studied.

- H03: Whether a respondent saves part of his income as a reserve does not depend on the field of study. 
- H04: Whether a respondent saves part of his income as a reserve does not depend on the level of study.

\section{Results and Discussion}

Furthermore, the attitude of the respondents was examined by asking whether they store a part of their income as a reserve in case of an unforeseen situation, i.e., whether they form a kind of financial reserve. Of the total number of respondents, $76.83 \%(1,104)$ declared that they saved part of their income for unforeseen situations or for other needs. Other respondents, $23.17 \%$ (333), stated that they do not create such a reserve. Within this question, four null hypotheses were tested, which were set out in Table 2.

Table 2. Depositing part of the income in the account as a reserve in relation to variables.

\begin{tabular}{|c|c|c|c|c|c|}
\hline $\begin{array}{c}\text { Hypothesis } \\
\text { No. }\end{array}$ & Wording of the zero hypothesis & $\chi^{2}$ & $\begin{array}{c}\text { Critical } \\
\text { value }\end{array}$ & $\begin{array}{c}\text { H0 can be } \\
\text { rejected }\end{array}$ & $\begin{array}{c}\text { Cramer's } \\
\text { V }\end{array}$ \\
\hline $\mathrm{H}_{1}$ & $\begin{array}{c}\text { Whether a respondent saves part of } \\
\text { his income as a reserve does not } \\
\text { depend on gender. }\end{array}$ & 6.66 & 3.84 & $\mathrm{X}$ & 0.09 \\
\hline $\mathrm{H}_{2}$ & $\begin{array}{c}\text { Whether a respondent saves part of } \\
\text { his income as a reserve does not } \\
\text { depend on the university studied. }\end{array}$ & 5.34 & 5.99 & - & - \\
\hline $\mathrm{H}_{3}$ & $\begin{array}{c}\text { Whether a respondent saves part of } \\
\text { his income as a reserve does not } \\
\text { depend on the field of study. }\end{array}$ & 13.10 & 3.84 & $\mathrm{X}$ & 0.10 \\
\hline $\mathrm{H} 0_{4}$ & $\begin{array}{c}\text { Whether a respondent saves part of } \\
\text { his income as a reserve does not } \\
\text { depend on the level of study. }\end{array}$ & 0.01 & 3.84 & - & - \\
\hline
\end{tabular}

Source: own research (2018)

Table 3 contains the results of the tested null hypotheses. It follows that the storage of part of the income as a reserve in case of an unforeseen situation is related to two variables.

Table 3. Depositing part of income as a reserve in relation to gender.

\begin{tabular}{|c|c|c|c|c|c|c|}
\hline \multirow{2}{*}{$\begin{array}{c}\text { Gender/ } \\
\text { response }\end{array}$} & $\begin{array}{c}\text { Absolute } \\
\text { frequenci } \\
\text { es }\end{array}$ & $\begin{array}{c}\text { Relative } \\
\text { frequencies } \\
\text { within } \\
\text { gender }\end{array}$ & $\begin{array}{c}\text { Absolute } \\
\text { frequenci } \\
\text { es }\end{array}$ & $\begin{array}{c}\text { Relative } \\
\text { frequencies } \\
\text { within } \\
\text { gender }\end{array}$ & $\begin{array}{c}\text { Absolut } \\
\text { e } \\
\text { frequen } \\
\text { cies }\end{array}$ & $\begin{array}{c}\text { Relative } \\
\text { frequencies } \\
\text { within gender }\end{array}$ \\
\hline Female & 655 & $79.30 \%$ & 171 & $20.70 \%$ & 826 & $100 \%$ \\
\hline Male & 449 & $73.49 \%$ & 162 & $26.51 \%$ & 611 & $100 \%$ \\
\hline Total & 1104 & $76.83 \%$ & 333 & $23.17 \%$ & 1437 & $100 \%$ \\
\hline & \multicolumn{2}{|c|}{ Value of adjusted residuals /sign notation } & \multicolumn{2}{|c|}{ Statistics } \\
\hline Female & 2.58 & ++ & -2.58 & -- & \multicolumn{2}{|c|}{$\chi 2>$ Critic. value } \\
Male & -2.58 & -- & 2.58 & ++ & \multicolumn{2}{c}{$6.66>3.84$} \\
\hline
\end{tabular}

Source: own research (2018)

The structure of the responses in relation to the gender of the respondents shows that more than half of those who answered that they save part of their income as a reserve are women. In the case of those who do not save such a reserve, the ratio of men and women is almost balanced. The value of the $\chi 2$ statistic is higher than the critical value at the 0.05 significance level. The null hypothesis can be rejected. Thus, the dependence between whether the respondent saves part of his income as a reserve and the sex of the respondents is proved. The value of Cramer's V is at the level of 0.09 , and it is, therefore, a very weak dependence. 
Dependencies between specific traits were found using adjusted residues. Their interpretation is aided by sign notation, from which it can be read that a statistically significant difference at the level of 0.01 is in women $(79.30 \%, 655)$, who to a greater extent than men $(73.49 \%$, 449) impose a part revenue as a reserve.

In the same question, the relationship between depositing income as a reserve and the focus of the studied faculty also manifested itself. The structure of the answers is given in Table 4.

Table 4. Depositing part of income as a reserve in relation to the focus of the studied faculty

\begin{tabular}{|c|c|c|c|c|c|c|}
\hline \multirow[b]{2}{*}{$\begin{array}{c}\text { Specializatio } \\
\text { n of the } \\
\text { faculty / } \\
\text { response }\end{array}$} & \multicolumn{2}{|c|}{ Yes } & \multicolumn{2}{|c|}{ No } & \multicolumn{2}{|c|}{ Total } \\
\hline & $\begin{array}{c}\text { Absolute } \\
\text { frequencie } \\
\text { s }\end{array}$ & $\begin{array}{c}\text { Relative } \\
\text { frequencie } \\
\mathbf{s} \text { within } \\
\text { faculties }\end{array}$ & $\begin{array}{c}\text { Absolute } \\
\text { frequencie } \\
\text { s }\end{array}$ & $\begin{array}{l}\text { Relative } \\
\text { frequencie } \\
\text { s within } \\
\text { faculties }\end{array}$ & $\begin{array}{c}\text { Absolute } \\
\text { frequencie } \\
\text { s }\end{array}$ & $\begin{array}{c}\text { Relative } \\
\text { frequencie } \\
\text { s within } \\
\text { faculties }\end{array}$ \\
\hline ECO & 672 & $73.77 \%$ & 239 & $26.23 \%$ & 911 & $100 \%$ \\
\hline NON-ECO & 432 & $82.13 \%$ & 94 & $17.87 \%$ & 526 & $100 \%$ \\
\hline \multirow[t]{2}{*}{ Total } & 1104 & $76.83 \%$ & 333 & $23.17 \%$ & 1437 & $100 \%$ \\
\hline & \multicolumn{4}{|c|}{ Value of adjusted residuals/sign notation } & \multicolumn{2}{|c|}{ Statistics } \\
\hline ECO & -3.62 & --- & 3.62 & +++ & \multirow{2}{*}{\multicolumn{2}{|c|}{$\begin{array}{c}\chi 2>\text { Crit. value } \\
13.10>3.84\end{array}$}} \\
\hline NON-ECO & 3.62 & +++ & -3.62 & --- & & \\
\hline
\end{tabular}

Source: own research (2018)

The value of the $\chi 2$ statistic is higher than the critical value at the 0.05 significance level. The null hypothesis can be rejected. Thus, the dependence between whether the student saves part of his income as a reserve and the focus of the faculty - economically oriented and noneconomically focused - is proved. The value of Cramer's V is at the level of 0.10 , and it is, therefore, a weak dependence. The difference between the empirical and the theoretical frequency at the significance level of 0.001 indicates the value of the adjusted residues, and thus a statistically significant dependence is demonstrated. The biggest difference in terms of theoretical and empirical frequencies is in the answer "no" for non-economically oriented students, where the empirical frequency differs from the theoretical frequency by more than $20 \%$. From the values of sign notation, it can be concluded that a more conscientious depositing of part of their income for unpredictable situations with students of noneconomically oriented faculties $(82.13 \%, 432)$.

In the case of depositing part of the income as a reserve, a statistical dependence was proved, where it was shown that women save part of their income as a reserve more often than men. Furthermore, students of non-economically oriented faculties save part of their income as a reserve compared to students of economically oriented faculties. Large differences between gender and financial literacy levels are demonstrated in many studies (Bannier and Schwarz, 2018; Bottazzi and Lusardi, 2020; Hsu et al., 2021). This indicates a responsible approach of university students to the realities of life, which is also in line with the statement of van Rooij et al. (2011), who believe that increasing financial literacy is associated with a higher and responsible approach to future planning. Garg and Singh (2018) also have this view. A similar trend can also be observed in the general population in the Czech Republic (PPM Factum, 2015), when income savings prevail among people with higher education (high school graduates and universities). Van Tuong and Minh Duc (2020) say also that financial literacy can be determined by many factors - such as gender, age, family status, education (field of study), permanent residents, And then financial literacy impact individual's saving 
behaviour, many studies were conducted to prove this (Amari et al., 2020; Anderson et al., 2017; Corsini and Giannelli, 2021; Widjaja et al., 2020).

\section{Conclusion}

The paper investigated financial literacy of university students in the Czech Republic. The results were obtained through a questionnaire survey which was conducted at three selected universities. The focus was on the area saving and management of income - store a part of income as a reserve in case of an unforeseen situation, i.e., whether they form a kind of financial reserve. It can be concluded that, of the total number of respondents, $76.83 \%$ declared that they saved part of their income for unforeseen situations or for other needs. Other respondents, $23.17 \%$, stated that they do not create such a reserve. Statistical evaluation proved a dependence between two variables - gender and field of study of respondents. The research was performed at the selected universities in the Czech Republic only, which may be considered as a limitation. Further research can focus on high schools to assess the development of financial literacy towards universities.

\section{References}

1. Amari, M., Salhi, B., \& Jarboui, A. (2020). Evaluating the effects of sociodemographic characteristics and financial education on saving behavior. International Journal of Sociology and Social Policy, 40(11/12), 1423-1438.

2. Anderson, A., Baker, F., \& Robinson, D. T. (2017). Precautionary savings, retirement planning and misperceptions of financial literacy. Journal of Financial Economics, 126(2), 383-398.

3. Bannier, Ch. E., \& Schwarz, M. (2018). Gender- and education-related effects of financial literacy and confidence on financial wealth. Journal of Economic Psychology, 67, 66-86.

4. Bottazzi, L., \& Lusardi, A. (2020). Stereotypes in financial literacy: Evidence from PISA. Journal of Corporate Finance, in press.

5. Corsini, L., \& Giannelli G. C. (2021). Economics education and financial literacy acquisition: Evidence from a field experiment. Journal of Behavioral and Experimental Finance, 32 .

6. Garg, N., \& Singh, S. (2018). Financial literacy among youth. IJSE, 45, 173-186.

7. Gilenko, E., \& Chernova, A. (2021). Saving behavior and financial literacy of Russian high school students: An application of a copula-based bivariate probit-regression approach. Children and Youth Services Review, 127.

8. Goyal, K., \& Kumar, S. (2021). Financial literacy: A systematic review and bibliometric analysis. International Journal of Consumer Studies, 45(1), 80-105.

9. Hendl, J. (2009). Přehled statistických metod: analýza a metaanalýza dat. Praha: Portál.

10. Hindls, R., Hronová, S., Seger, J., \& Fischer, J. (2007). Statistika pro ekonomy. Praha: Professional publishing.

11. Hsu, Y.-L, Chen, H.-L., Huang P.-K., \& Lin, W-Y. (2021). Does financial literacy mitigate gender differences in investment behavioral bias? Finance Research Letters, 41.

12. Kurowski, L. (2021). Household's Overindebtedness during the COVID-19 Crisis: The Role of Debt and Financial Literacy. Risks, 9(62). 
13. MF ČR - PPM factum research (2015). Výsledky měrení finanční gramotnosti 2015, Ministerstvo finanční ČR: Proč se finančně vzdělávat?. https://www.psfv.cz/cs/proodborniky/mereni-urovne-financni-gramotnosti/2015/mereni-urovne-financnigramotnosti-2784.

14. Morgan, P., \& Trinh, L. (2019). Determinants and Impacts of Financial Literacy in Cambodia and Viet Nam. Journal of Risk and Financial Management, 12(1), 1-24.

15. OECD, (2018). OECD/INFE Core competencies framework on financial literacy for MSMEs. $\quad$ https://www.oecd.org/finance/financial-education/OECD-INFE-corecompetencies-framework-on-financial-literacy-for-MSMEs.pdf.

16. van Rooij, M. C. J., Lusardi, A., \& Alessie, R. J. M. (2011). Financial literacy and retirement planning in the Netherlands., Journal of Economic Psychology, 32, 593-608.

17. Van Tuong, N., \& Minh Duc, D., (2020). The Correlation between Financial Literacy and Personal Saving Behavior in Vietnam. Asian Economic and Financial Review, 10(6), 590-603.

18. Widjaja, I., Arifin, A.-Z., \& Setini, M. (2020). The effects of financial literacy and subjective norms on saving behavior. Management Science Letters, 10, 3635-3642.

19. Yuesti, A., Rustiarini, N. W., \& Suryandari, N. N. A. (2020). Financial literacy in the COVID-19 pandemic: pressure conditions in Indonesia. Entrepreneurship and Sustainability Issues, 8(1), 884-898. 